\title{
Construction of Student Mathematics Resilience Through the Development of Sainsmatika-Based Teaching Materials
}

\author{
Neli Agustin ${ }^{1 *}\left(\right.$ (D) , Muchamad Subali Noto ${ }^{1}$ (D), Irmawati Liliana Kusuma Dewi ${ }^{1}$ (D)
}

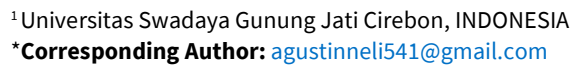

Citation: Agustin, N., Noto, M. S., \& Dewi, I. L. K. (2022). Construction of Student Mathematics Resilience Through the Development of SainsmatikaBased Teaching Materials. International Electronic Journal of Mathematics Education, 17(2), em0683. https://doi.org/10.29333/iejme/11835

\begin{abstract}
ARTICLE INFO
Received: 27 Oct. 2021

Accepted: 25 Feb. 2022

ABSTRACT

Mathematical resilience is an internal factor in students that is important to have in dealing with learning mathematics. This study aims to design efforts to construct mathematical resilience and develop sainsmatikabased teaching materials in constructing students' mathematical resilience. The research method used is the design method (design research) with a qualitative approach. The design of this study uses the model proposed by Plomp and Nieveen (2007) which includes preliminary research, namely analyzing the level of students' mathematical resilience, conducting a literature review, and developing a conceptual or theoretical framework for research. Prototyping stage, the process of designing teaching materials that is developed repeatedly is the design of the Pythagorean module based on sainsmatika. The last is the assessment phase, by evaluating the extent to which the modules designed provide solutions in constructing students' mathematical resilience. The validation results show that the module category is at a very feasible level for use with a percentage of $89.84 \%$, covering aspects of content feasibility assessment of $92.43 \%$, presentation feasibility of $91.66 \%$, language feasibility of $84.25 \%$, and assessment of sainsmatika elements. by $91.68 \%$. So that the module that has been designed is very feasible to use as a form of constructing students' mathematical resilience.
\end{abstract}

Keywords: mathematical resilience, mathematical resilience construction, development of sainsmatika-based teaching materials

\section{INTRODUCTION}

Education is an effort that can accelerate the development of human potential (Sa'ud \& Makmun, 2006). In the Dictionary of Education, Sa'ud and Makmun (2006) state that education is a process by which a person develops the ability, attitudes, and other forms of behavior in the society in which he lives, a social process in which people are exposed to selected and controlled environmental influences, so that they can acquire and experience the development of optimal social and individual abilities. One of the potential developments in this educational process is contained in learning mathematics.

In dealing with learning mathematics, it is necessary to have mathematical resilience. Mathematical resilience is an important internal factor for students to have in dealing with mathematics learning. Komala (2017) states that students who have strong resilience will have the necessary mathematical skills and are willing to apply them in everyday life. Students who have mathematical resilience skills not only master the theory, but also have the ability to adapt to any problems they face and communicate with other individuals while maintaining their identity. So that the effort to construct mathematical resilience becomes a series of attitudes that can provide a positive response to learning mathematics (Rafiana \& Adirakasiwi, 2019). Based on these things, so that mathematics learning can be delivered effectively and can construct students' mathematical resilience, a new innovation is needed, one of which is the use of innovative teaching materials media. Module development efforts can be made to help improve students' mathematical resilience (Ahmad, 2017). In line with Asih's (2020) research, which states that there is an increase in mathematical resilience in classes that are given module-assisted learning/teaching materials.

In learning mathematics integration is very necessary in facilitating student understanding. As well as integration with science, based on research by Wangid et al. (2016) which states that science and mathematics are two subjects that can be integrated because both can be linked to contextual daily life. This is in line with Dewi and Hasanah (2017) which states that one way to interpret mathematics lessons is to apply integrated values to the material being studied. According to the Webster's New Collegiate Dictionary in Safira and Ifadah (2020), science is an observational activity and a series of experiments in finding answers related to the reality that exists in the surrounding environment, while mathematics is a mindset, logical organization and proof, which becomes a series of problem solving. Based on the above potential, this research seeks to construct students' mathematical resilience by developing sainsmatika-based teaching materials. 


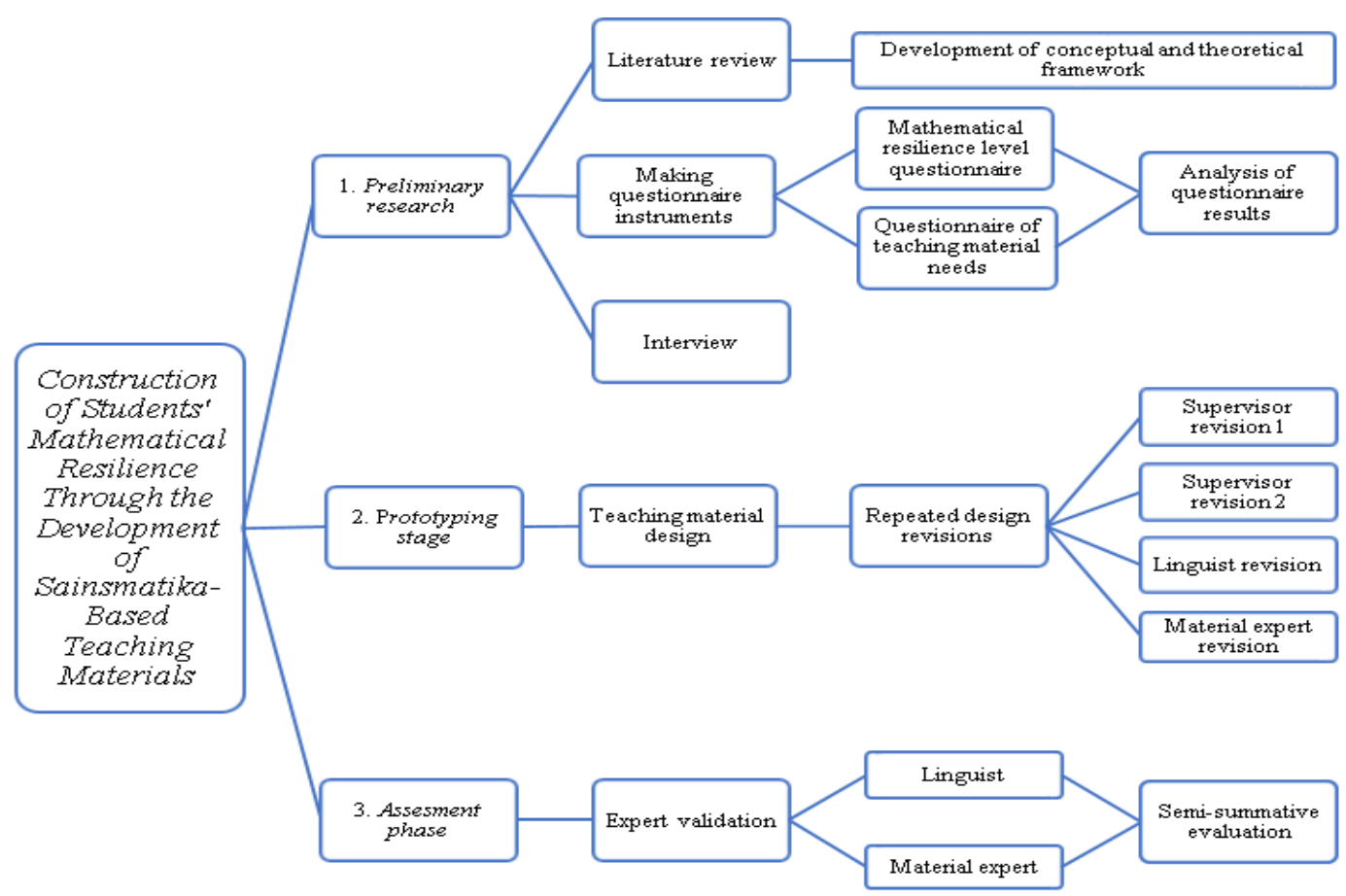

Figure 1. Research framework

\section{METHOD}

This study uses design research methods by conducting systematic assessments related to designing, developing and evaluating learning materials as solutions to problem solving in education (Plomp \& Nieveen, 2007). Barab and Squire (2004) state that design-based research is not an approach but a series of approaches with the aim of generating new theories, products and practices that explain and have the potential to impact learning and teaching in naturalistic settings. According to Edelson (2006), the design method is a method that captures and makes explicit decisions regarding the design process and turns them into guidelines for addressing educational problems. This study aims to develop research-based solutions to complex problems in educational practice. This study uses research methods of design (design research) by assessing systematically related to design, develop, and evaluator of learning materials as solutions to problems in education (Plomp \& Nieveen, 2007). Based on the design research model proposed by Plomp and Nieveen (2007), the development procedure in this study follows the following steps:

1. Preliminary research: At this stage, the researcher conducts the needs and context analysis process, literature review, and the development of a conceptual or theoretical framework for research. Data analysis was carried out through the provision of a questionnaire instrument in the form of a mathematical resilience level questionnaire and a questionnaire on the need for sainsmatika-based teaching materials. Aspects/characteristics, indicators, and statements of the two questionnaires used, as well as the form of the questionnaire are contained in attachments 1, 2, 3, 4, 5, and 6. Then from the results of the questionnaire, the interview process was carried out by reconfirming the statements in the questionnaire to three students as samples. The sample selection was done by random sampling and the questionnaire was distributed online through the help of Google form. In addition to providing questionnaires and interviews, a literature review was carried out by multiplying references from the results of previous studies that discussed the development of teaching materials and the construction of mathematical resilience. The collected data is then analyzed using descriptive quantitative analysis techniques, and a research development framework is made.

2. Prototyping stage: Based on the results of the analysis in the previous stage, at this stage the design process will be carried out. The design begins by creating a flow of module content, then wrapping the Pythagorean material in a sainsmatikabased module. This design stage is carried out repeatedly by revising the module based on suggestions for improvement from supervisors, linguists, and material experts. It aims to improve and refine the research module.

3. Assessment phase: This stage is carried out by evaluating the extent to which the designed modules provide solutions in building students' mathematical resilience. Efforts are made by conducting a validation process. Previously, each student's mathematical resilience questionnaire statement was validated with valid and invalid assessment criteria. This is done to determine the level of validity of the mathematical resilience questionnaire instrument used and so that the conclusion of the analysis of the mathematical resilience level of students obtains the correct data to be constructed in the designed module. Then the module design is validated with the validation questionnaire attached in attachments 7 and 8; and evaluated through the four assessment criteria, as follows: 1: not feasible, 2: less worthy, 3: worthy, and 4: very worthy. This validation was carried out by 1 linguist and 2 material expert lecturers. This stage produces recommendations for improvement of the intervention and is referred to as the semi-summative phase.

The research design is systematically represented in the research framework in Figure 1. 


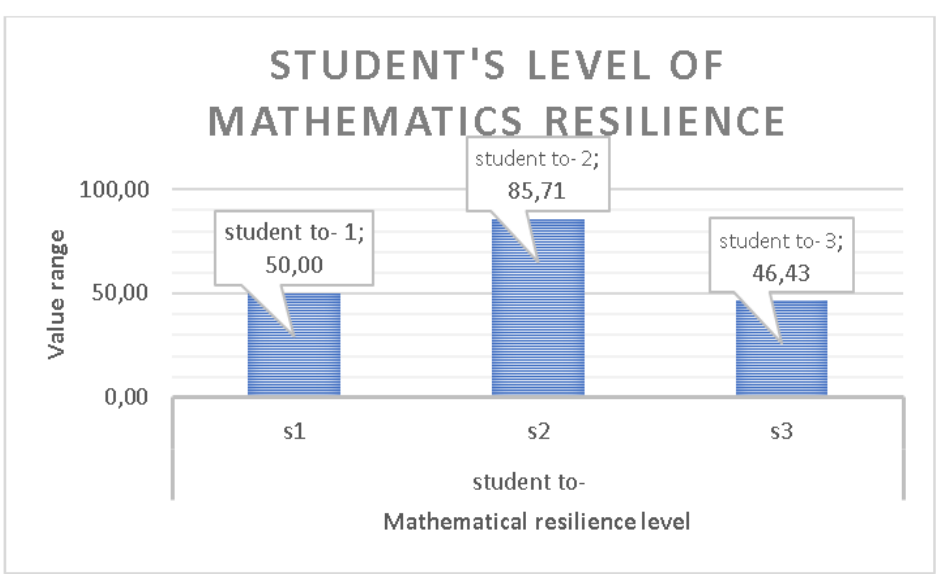

Figure 2. Student's mathematical resilience level

\section{The Level of Need for Sainsmatika-Based Teching Materials}

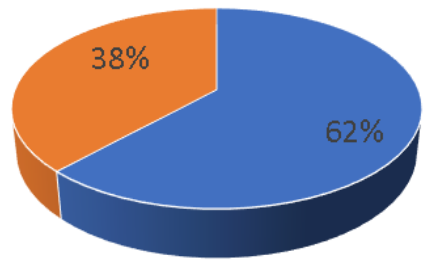

- High Category - Low Category

Figure 3. Level of need for sainsmatika-based teaching materials

\section{RESULTS}

\section{Student's Mathematical Resilience Level}

The assessment of the level of mathematical resilience was carried out by filling in the Google form and interviewing 28 statements. The data on the level of mathematical resilience of students from 3 research samples are presented in Figure 2. Based on the range of mathematical resilience criteria, it is known that two of them have a low level of resilience, and one student has a high level of resilience. Therefore, it is necessary to construct the level of students' mathematical resilience.

\section{The Level of Student Need for Innovation in Sainsmatika-Based Teaching Materials}

Analysis of the level of need for teaching materials was carried out through a questionnaire instrument of 27 written statements which were used to obtain information related to the level of student need for innovation in sainsmatika-based teaching materials. From the results of the overall analysis related to the level of need for sainsmatika-based teaching materials, it is presented in Figure 3.

Analysis of the results of the questionnaire on the level of needs for sainsmatika teaching materials showed $62 \%$, which in the range of criteria values for the level of needs for teaching materials were in high criteria. Researchers also conducted interviews as a form of strengthening the results of the questionnaire. The following is a snippet of the interview results:

Researcher: Do you really need teaching materials other than textbooks?

Student 1: Really need it.

Researcher: With the teaching materials that are currently used, do you understand mathematics?

Student 1: Sometimes I like to understand, the rest I don't.

Researcher: Is it difficult to learn mathematics from the Pythagorean material independently through the textbook you use? 


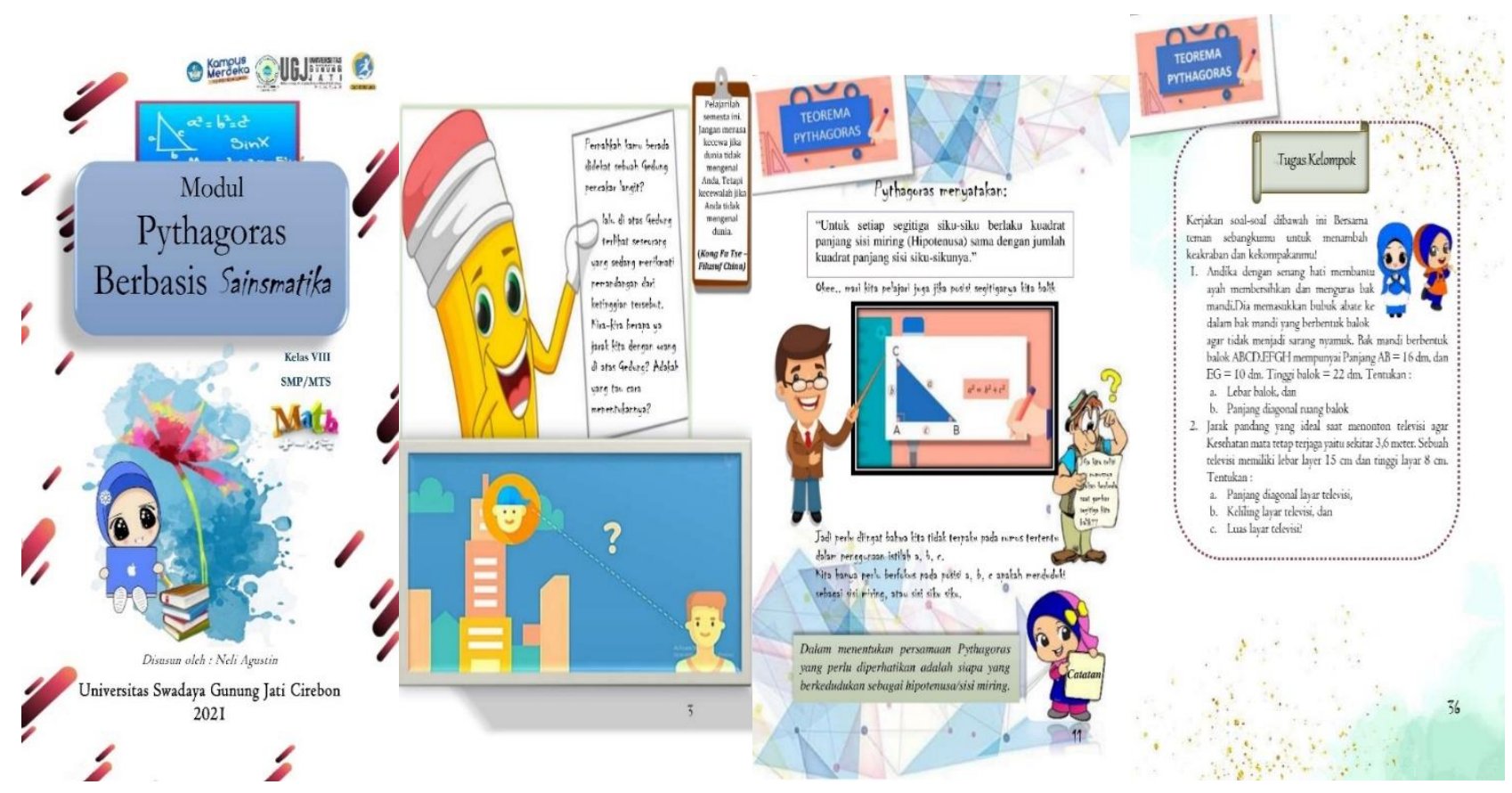

Figure 4. Design of a sainsmatika-based Pythagorean module

Student 2: Yes.

Researcher: If there is an innovative textbook that combines Pythagorean science and mathematics, would you want to use it?

Student 2: Want.

Researcher: Have you ever tried as an example a teacher giving innovative textbooks for certain materials?

Student 2: No, never.

Researcher: Do you think there is a need for textbooks other than the textbooks that are currently being used?

Student 3: Need.

Researcher: Are the teaching materials that you are currently using make you excited or not in learning?

Student 3: No.

Researcher: In your opinion, do the teaching materials used now provide an opportunity for you to do the practice questions independently?

Student 3: No.

Researcher: If there is an innovative Pythagorean material textbook that adapts to the development of science, for example mathematics combined with science, do you want to use it?

Student 3: Yes.

From the results of the analysis above, it can be concluded that students have a high level of need related to the innovation of sainsmatika-based teaching materials. This encourages an effort to design a sainsmatika-based Pythagorean module design in constructing the level of mathematical resilience.

\section{Sainsmatika-Based Teaching Material Design}

The design in this study is a concept of developing teaching materials which is expected to be an alternative innovation of teaching materials for mathematics teachers of SMP class VIII. The development of the design of this teaching material is made in the form of a learning module. The module that addresses the Pythagorean material is arranged based on its implications as an effort to construct mathematical resilience abilities accompanied by the development of sainsmatika values. Some design drafts for the development of the sainsmatika-based Pythagorean module are presented in Figure 4. 


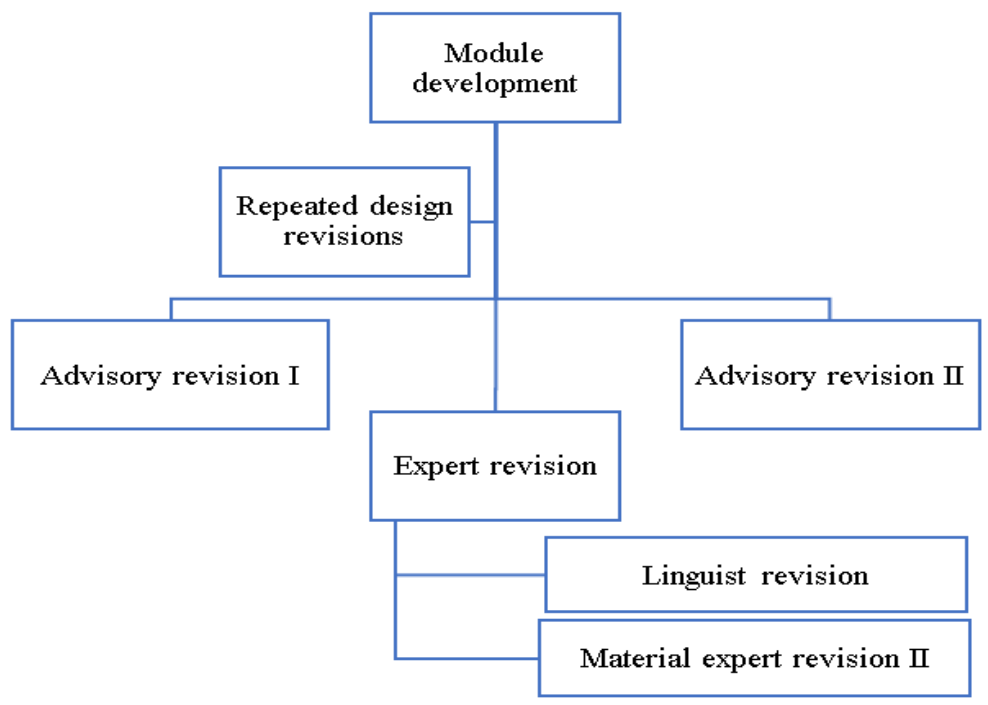

Figure 5. Pythagorean module design improvement flow based on sainsmatika

Table 1. Validation test results for content feasibility aspects

\begin{tabular}{lcccc}
\hline Validator & Score & Maximum score & Percentage & Category \\
\hline Linguist & 41 & 44 & 93.18 & Very worthy \\
\hline Material expert I & 41 & 44 & 93.18 & Very worthy \\
\hline Material expert II & 40 & 44 & 90.90 & Very worthy \\
\hline Average & $\mathbf{4 0 . 6 7}$ & $\mathbf{4 4}$ & $\mathbf{9 2 . 4 3}$ & Very worthy \\
\hline
\end{tabular}

Table 2. Results of the validation of the feasibility aspects of presentation

\begin{tabular}{lcccc}
\hline Validator & Score & Maximum score & Percentage & Category \\
\hline Linguist & 30 & 32 & 93.75 & Very worthy \\
\hline Material expert I & 29 & 32 & 90.63 & Very worthy \\
\hline Material expert II & 29 & 32 & 90.63 & Very worthy \\
\hline Average & $\mathbf{2 9 . 3 3}$ & $\mathbf{3 2}$ & $\mathbf{9 1 . 6 6}$ & Very worthy \\
\hline
\end{tabular}

Table 3. Results of the validation of the language feasibility aspects

\begin{tabular}{lcccc}
\hline Validator & Score & Maximum score & Percentage & Category \\
\hline Linguist & 32 & 36 & 88.89 & Very worthy \\
\hline Material expert I & 32 & 36 & 88.89 & Very worthy \\
\hline Material expert II & 27 & 36 & 75.00 & Worthy \\
\hline Average & $\mathbf{3 0 . 3 3}$ & $\mathbf{3 6}$ & $\mathbf{8 4 . 2 5}$ & Very worthy \\
\hline
\end{tabular}

In the module development stage before the assessment process is carried out, the module is revised repeatedly. The process of repairing this module includes the stages of improvement which are presented in Figure 5.

The draft module that has been designed then goes through an assessment or validation stage from a competent expert in the field of language and materials. The purpose of this assessment is to determine the feasibility of the module that has been designed. The module validity/validity test involved two material experts and one linguist. This validation test was conducted to determine the level of validity of the developed module. Aspects assessed include aspects of content feasibility, presentation feasibility, language feasibility, and assessment of sainsmatika elements, as follows:

1. The calculation of the validity test for the presentation aspect consists of four assessment criteria can be seen in Table 1 . From Table 1, it is known that the calculation of the validity test for the content feasibility aspect is in the very feasible category with a percentage of $92.43 \%$.

2. The calculation of the validity test for the presentation feasibility aspect consists of three assessment criteria can be seen in Table 2. From Table 2, it is known that the calculation of the validity test for the presentation feasibility aspect is in the very feasible category with a percentage of $91.66 \%$.

3. The calculation of the validity test for the language feasibility aspect consists of five assessment criteria can be seen in Table 3. From Table 3, it is known that the calculation of the validity test for the language feasibility aspect is in the very feasible category with a percentage of $84.25 \%$.

4. The calculation of the validity test for the sainsmatika assessment aspect consists of two assessment criteria can be seen in Table 4. From Table 4, it is known that the calculation of the validity test for aspects of the assessment of sainsmatika elements is in the very feasible category with a percentage of $91.68 \%$. 
Table 4. Validation test results for sainsmatika assessment aspects

\begin{tabular}{lcccc}
\hline Validator & Score & Maximum score & Percentage & Category \\
\hline Linguist & 15 & 16 & 93.75 & Very worthy \\
\hline Material expert I & 14 & 16 & 87.50 & Very worthy \\
\hline Material expert II & 15 & 16 & 93.75 & Very Worthy \\
\hline Average & $\mathbf{1 4 . 6 7}$ & $\mathbf{1 6}$ & $\mathbf{9 1 . 6 8}$ & Very worthy \\
\hline
\end{tabular}

Table 5. Results of the Pythagorean module validation test based on sainsmatika

\begin{tabular}{lcccc}
\hline Validator & Score & Maximum score & Percentage & Category \\
\hline Linguist & 118 & 128 & 92.19 & Very worthy \\
\hline Material expert I & 116 & 128 & 90.63 & Very worthy \\
\hline Material expert II & 111 & 128 & 86.72 & Very Worthy \\
\hline Average & $\mathbf{1 1 5}$ & 128 & $\mathbf{8 9 . 8 4}$ & Very worthy \\
\hline
\end{tabular}

From the four aspects of the assessment above, it can be stated the feasibility of the overall module development design. The following is a calculation of the validity of the Pythagorean module based on science from the four aspects of the assessment presented in Table 5.

The results of the module validation test carried out by two material experts and one linguist illustrate sainsmatika-based Pythagorean module is in the very suitable category for use.

\section{Description}

a. Linguist: Mrs. Hesti Muliawati, SS, M.Pd

b. Material expert I: Mrs. Ika Wahyuni, S.Pd., M.Si

c. Material expert II: Mrs. Laelasari, M.Pd

\section{DISCUSSION}

\section{Student's Mathematical Resilience Level}

From the results of the analysis of the level of mathematical resilience carried out, it shows the need for construction efforts. Based on the range of mathematical resilience criteria, it is known that two of them have a low level of resilience, and one student has a high level of resilience. Therefore, it is necessary to construct the level of students' mathematical resilience.

\section{Students' Mathematical Resilience Construction Efforts}

From the results of research related to the level of students' mathematical resilience, it refers to the need for efforts to construct mathematical resilience. This is also supported by the results of the questionnaire on the level of need for science teaching materials as an effort to construct students' mathematical resilience. The results of the questionnaire are in the high category range, which is $62 \%$.

Efforts to construct mathematical resilience are also supported by the results of previous studies regarding the importance of mathematical resilience. Among them, mathematical resilience is needed to encourage effective mathematics learning (Lugalia et al., 2013). Students who have high mathematical resilience will support the success of the mathematics learning process even in situations and conditions that they do not like. Resilience can help students overcome difficulties in solving mathematical problems (Maharani \& Bernard, 2018).

The research of Asih et al. (2019) also shows that mathematical resilience has a fairly high contribution to students' mathematical understanding abilities. This indicates that resilience is an important ability to be possessed by students. So that the development of the module in an effort to construct students' mathematical resilience is a series of important things that will be carried out in line with Asih's (2020) research, which states that the module is not only used to familiarize students with independent learning as well as an effort to improve students' resilience abilities.

\section{Development of Sainsmatika-Based Modules in Constructing Students' Mathematical Resilience}

The preparation of a sainsmatika-based Pythagorean module to improve students' mathematical resilience begins with a needs analysis that has been described previously. After knowing the need for efforts to construct mathematical resilience, then a module design is prepared according to these implications. The design of this module is structured to address the problems experienced by students. The design of the module is carried out repeatedly in accordance with the suggestions for improvement of two supervisors, one linguist, and two material expert lecturers. The module prototype design process includes content criteria that contain aspects of mathematical resilience to support the improvement and construction of students' mathematical resilience levels which include four aspects quoted from (Johnston-Wilder et al., 2014), as follows:

1. Understanding of math grades: An understanding of the value of mathematics in the module is presented in the module flow as well as an introduction to the Pythagorean Theorem material which is carried out through observation activities and the inclusion of truth-checking steps in the material presented. 


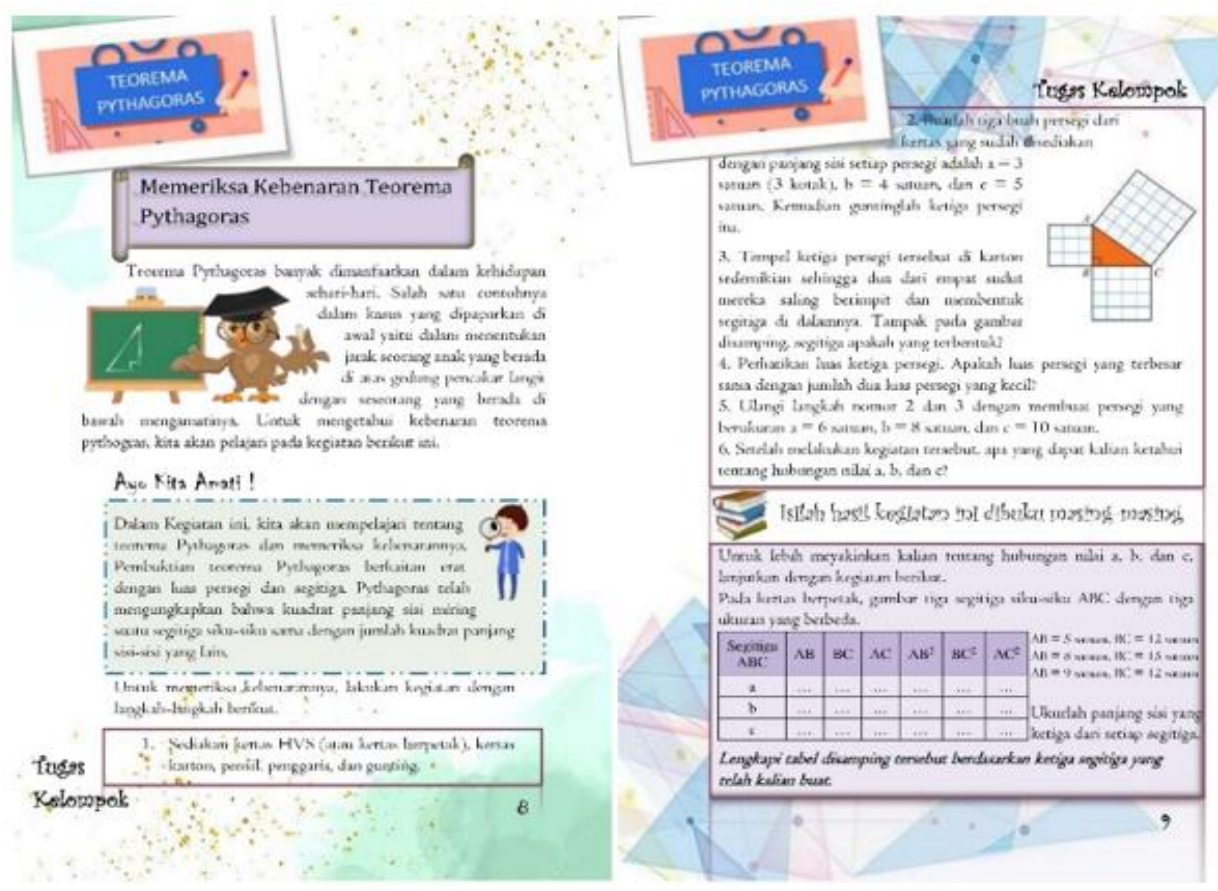

Figure 6. Introduction to the value of mathematics through the examination of the Pythagorean Theorem

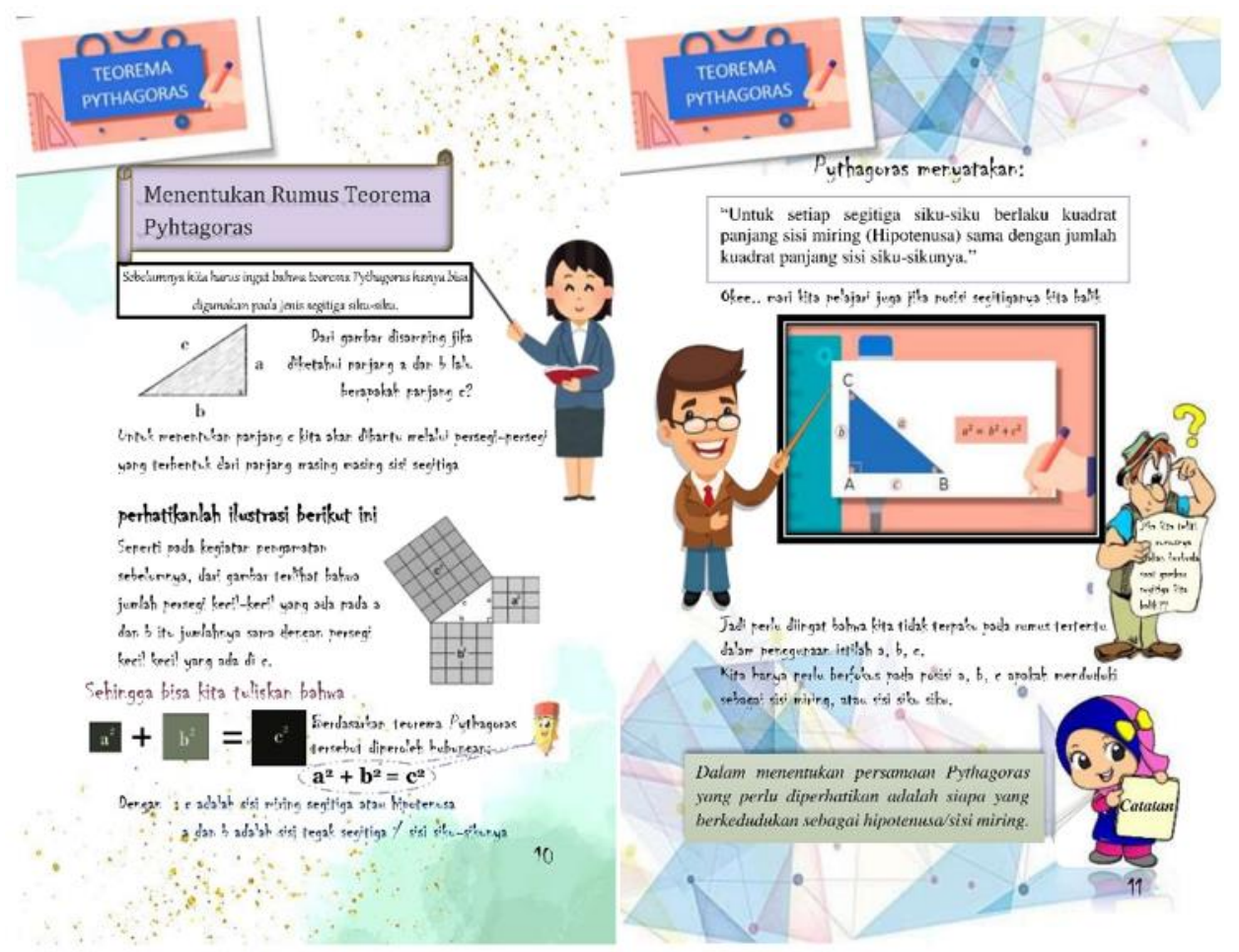

Figure 7. The introduction of mathematical values through the introduction of the Pythagorean Theorem formula

Figure 6 represents the value of mathematics through Pythagorean value checking activities. Figure 6 describes the activities of examining the Pythagorean Theorem. Students are invited to understand the Pythagorean values through the experience gained from these activities. This is in line with the research of Mawaddah and Maryanti (2016), which states that knowledge will stick longer if students are directly involved in the process of understanding and constructing the concepts and knowledge themselves.

In addition, the introduction of values is also found in the activity of determining the Pythagorean Theorem formula which is presented in Figure 7. It is important to pay attention to the values contained in mathematics (Dewi \& Hasanah, 2017). Therefore, the activity of determining the formula for the Pythagorean Theorem contributes to helping students understand the Pythagorean concept in the module as presented in Figure 7. 


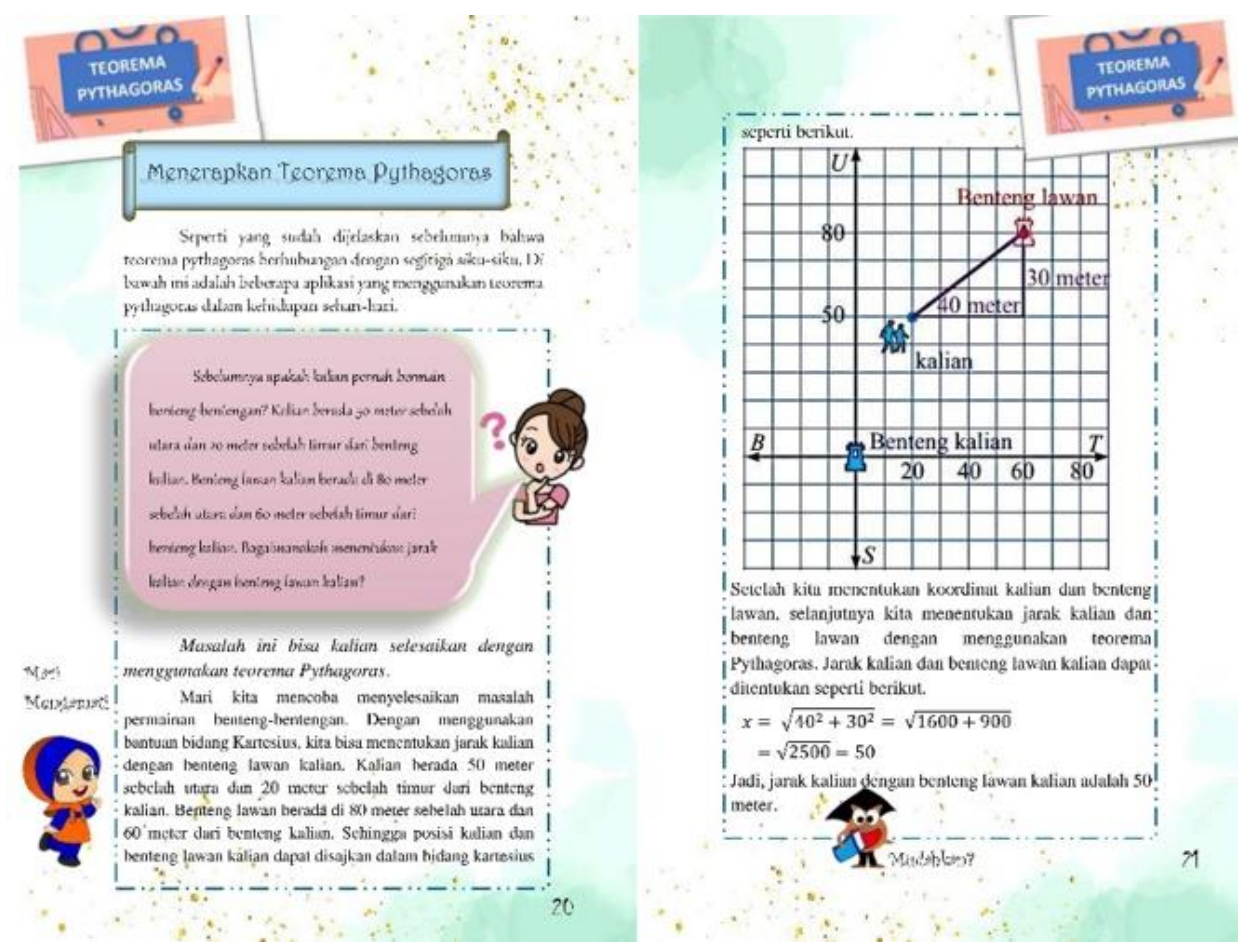

Figure 8. Building a growth mindset through the presentation of implementable materials

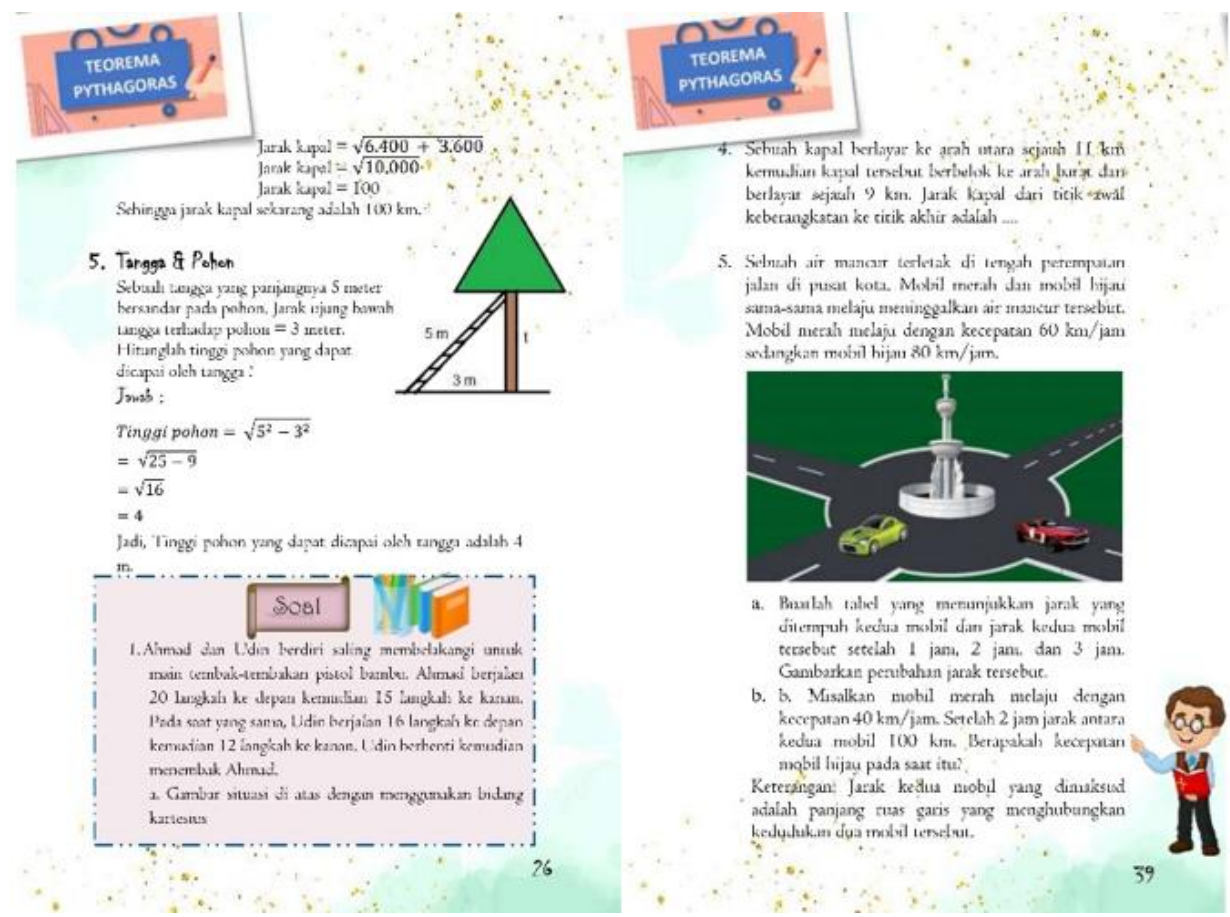

Figure 9. Building a growth mindset through the inclusion of varied questions

2. Growth mindset: In building the aspect of students' growth mindset, it is presented in modules with the inclusion of varied questions and the presentation of implementable material to support the process of increasing students' cognitive abilities and help develop their thinking processes. The cultivation of a growth mindset presented in Figure $\mathbf{8}$. Figure $\mathbf{8}$ is a form of material presentation that is implemented as an effort to adapt strategies in constructing students' mathematical resilience. The research by Irawan and Kencanawaty (2017) stated that exploring the line of life that is related to mathematics becomes very enjoyable for students.

As for building a growth mindset in the inclusion of varied questions, it is presented in Figure 9. Figure 9 is a presentation of the solution from the research results stating that the growth mindset aspect in students' mathematical resilience abilities is only 50.00, which means that it is in the low criteria range. Putranti and Prahmana (2018) revealed that the decline in the achievement of the ability aspect in solving problem-based mathematics problems occurred because of learning resources. Through the presentation of varied questions in this module, it helps students in developing their thinking skills so that they can construct a student's growth mindset. 


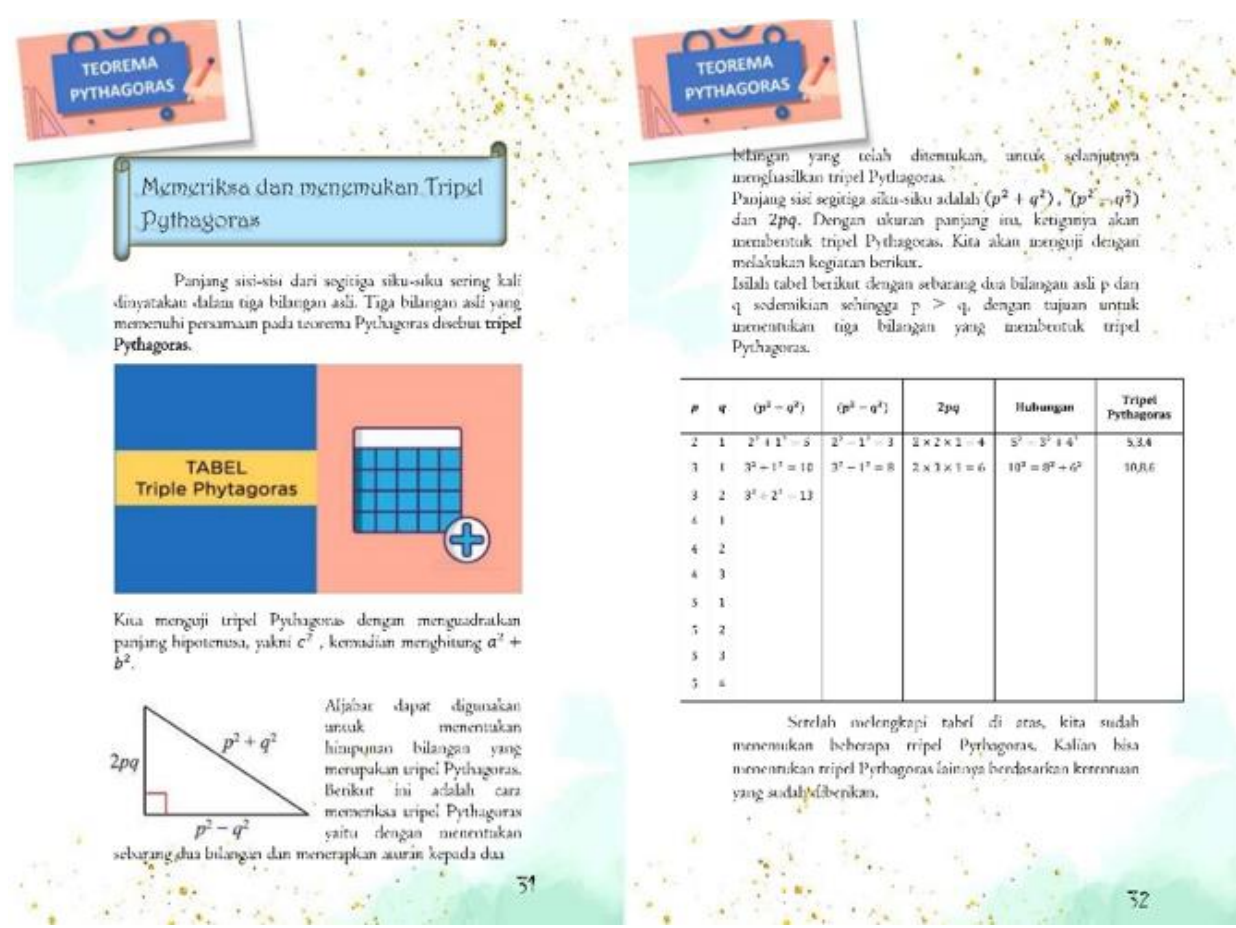

Figure 10. Understanding of how to work in mathematics

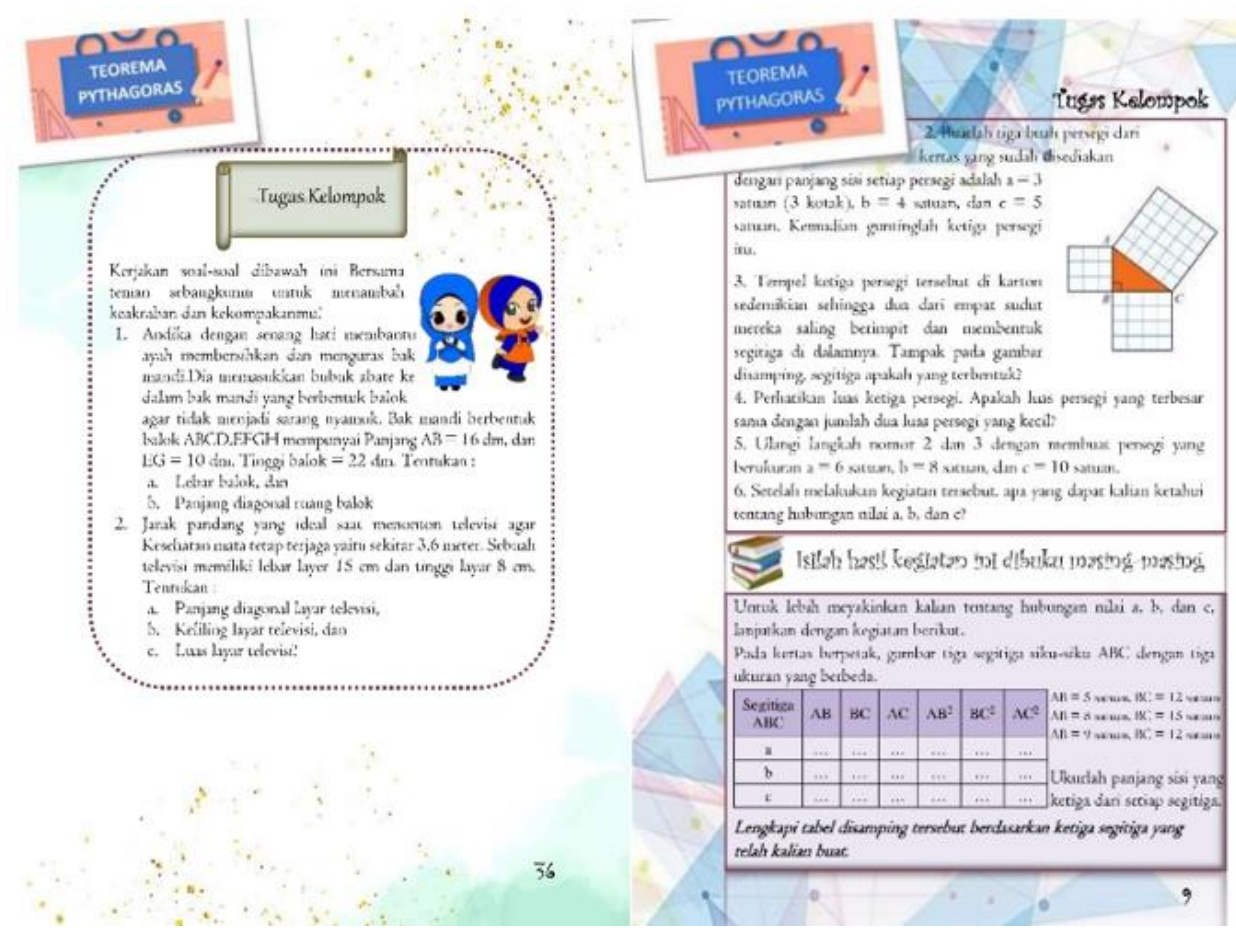

Figure 11. Understanding of how to work in mathematics through group-based activities

3. Understanding of how to work in math: The construction of the third aspect is carried out by giving students the opportunity to experiment through various observation activities and group task-based activities. An inculcation of understanding to students about how to work in mathematics is presented in Figure 10. Figure 10 is a form of solution from the results of the study stating 50.00 scores for aspects of students' understanding of how to work in mathematics, which means that they are in the low criteria range. Through the activity of completing the Pythagorean triple, students are taught how to do mathematics through pre-existing patterns.

In addition, an introduction to how to do mathematics is also found in group-based activities presented in Figure 11. In the context of learning, resilience in this aspect is a concept about students' abilities in dealing with problems and obstacles that seem impossible to overcome (Goodall \& Johnston-Wilder, 2015). Figure 11 describes aspects that describe the struggle in facing and overcoming obstacles, one of which is through group-based activities and student experimentation activities. 


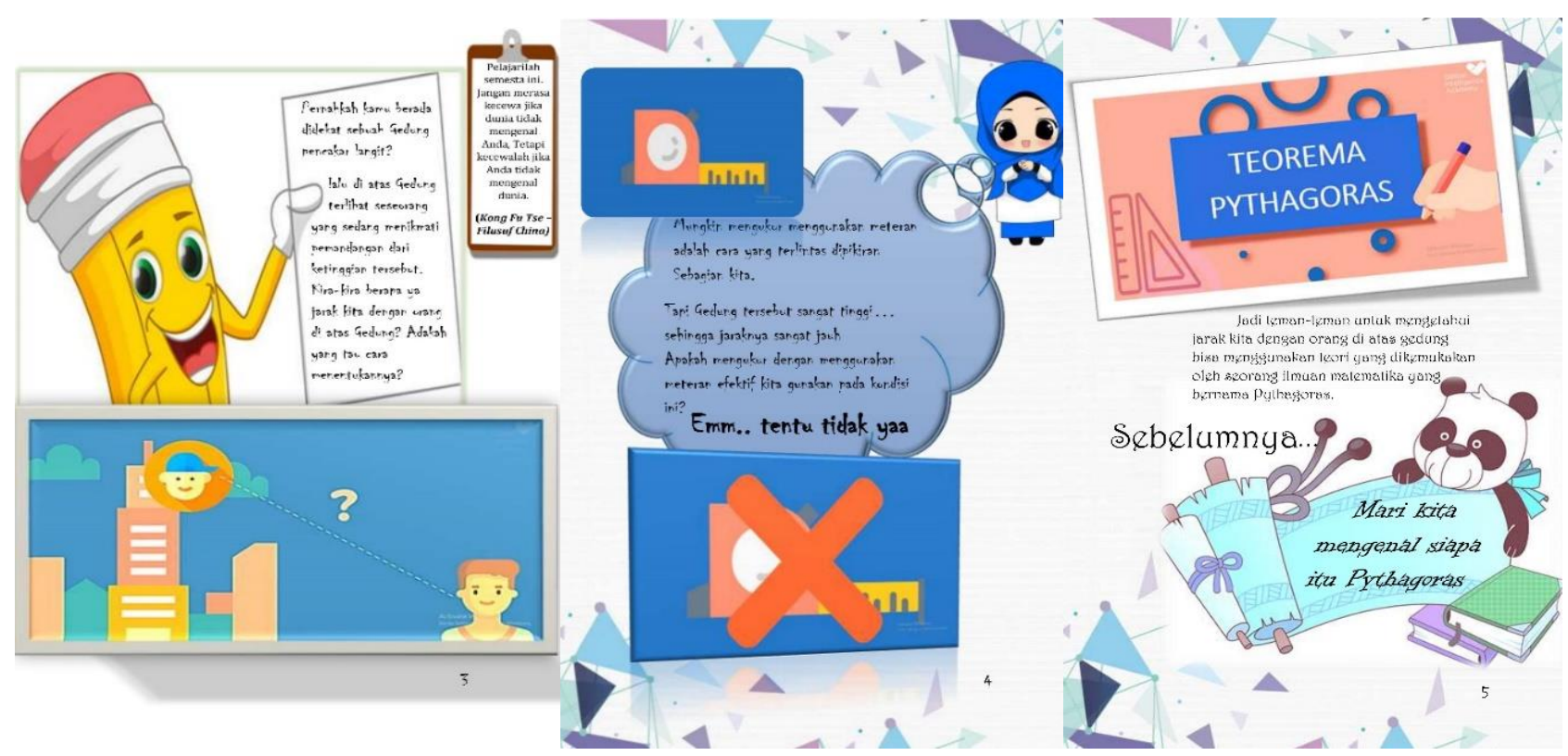

Figure 12. Awareness of support

4. Awareness of support: Around $90.48 \%$ of students are aware of the support. Therefore, in this effort to build mathematical resilience, module development innovations are made by providing interesting illustrations that can support the delivery of the material presented by the module. The construction of the awareness aspect of support is presented in Figure 12. Figure 12 illustrates the awareness aspect of reinforced support in the flow of material delivery that is made coherent and interesting so that students are easier to understand the material presented.

The content of the module is designed by elevating elements of science and mathematics that are integrated. In line with research (Nurhidayah \& Wangid, 2020), which states that the results of research on developing teaching material products in the form of sainsmatika-based fairy tale books prove that fun teaching materials can have a positive effect on the learning process. The sainsmatika element in this module lies in the introduction, how to present the material and the selection of questions presented in the module. The completeness of the elements in the design of this module then goes through the assessment stage or expert validation to determine the feasibility of the module that has been designed.

The validation stage is carried out by evaluating the extent to which the designed module provides solutions in building students' mathematical resilience. The validation results show that the module category is at a very feasible level for use with a percentage of $89.84 \%$. The validation of this module includes aspects of content feasibility assessment of $92.43 \%$, presentation feasibility of $91.66 \%$, language feasibility of $84.25 \%$, and assessment of sainsmatika elements of $91.68 \%$.

The inputs given by the validator include improvements in the use of sentences, improvements in setting the writing distance, adding flat libraries, and improving the use of numbers in sample questions. The conclusion from the results of the module that has been designed is feasible to be used as a means of constructing students' mathematical resilience.

\section{CONCLUSIONS}

From the results of the analysis of the level of mathematical resilience of SMP class VIII students in Kuningan regency, it shows the need for construction efforts. Analysis of the results of the questionnaire on the level of need for sainsmatika teaching materials showed $62 \%$ and was in the high criteria range. This encourages an effort to design a sainsmatika-based pythagorean module design in an effort to construct the level of students' mathematical resilience. This research produces teaching materials in the form of a sainsmatika-based pythagorean module which is designed to contain elements of mathematical resilience as a form of efforts to construct students' mathematical resilience. The module was validated by two material experts from the mathematics education lecturer at the Teacher Training and Education Faculty, Swadaya Gunung Jati University and one language expert lecturer from the Indonesian Language Education study program, the Teacher Training and Education Faculty, Swadaya Gunung Jati University. In assessing aspects of content feasibility, presentation feasibility, language feasibility, and assessment of sainsmatika elements, the sainsmatika-based Pythagorean module is stated to be very suitable for use in learning mathematics in schools. Because this research was conducted as a form of lecture final project with a limited time span, so the drawback of this research is the imperfection of the results because there is no module implementation process for students at school. So it is hoped that there will be further studies that will continue this research.

Author contributions: All authors have sufficiently contributed to the study, and agreed with the results and conclusions.

Funding: No funding source is reported for this study.

Declaration of interest: No conflict of interest is declared by authors. 


\section{REFERENCES}

Ahmad, S. (2017). Pengembangan modul bimbingan pribadi sosial untuk meningkatkan resiliensi siswa korban bullying [Development of a personal social guidance module to increase the resilience of students who are victims of bullying]. Jurnal Psikologi Pendidikan \& Konseling [Journal of Educational \& Counseling Psychology], 3(2), 82-89. https://doi.org/10.26858/.jpkk. v0i0.3067

Asih, K. S. (2020). Komunikasi matematika ditinjau dari resiliensi matematis pada pembelajaran mandiri berbantuan modul dan discovery learning berbantuan e-learning [Mathematical communication in terms of mathematical resilience in module-assisted independent learning and e-learning assisted discovery learning] [Thesis, Program Studi Pendidikan Matematika Pascasarjana UNNES-UNNES Postgraduate Mathematics Education Study Program].

Asih, K. S., Isnarto, I., Sukestiyarno, S., \& Wardono, W. (2019). Resiliensi matematis pada pembelajaran discovery learning dalam upaya meningkatkan komunikasi matematika [Mathematical resilience in discovery learning in an effort to improve mathematical communication]. In Prosiding Seminar Nasional Matematika [Proceedings of the National Mathematics Seminar] (pp. 862-868).

Dewi, H. L., \& Hasanah, A. (2017). Penerapan pembelajaran nilai-nilai yang terintegrasi pada materi matematika SMA kelas XI [Penerapan pembelajaran nilai-nilai yang terintegrasi pada materi matematika SMA kelas XI]. In Prosiding Seminar Matematika Dan Pendidikan Matematika UNY [Proceedings of the UNY Mathematics and Mathematics Education Seminar] (pp. 115-122).

Goodall, J., \& Johnston-Wilder, S. (2015). Overcoming mathematical helplessness and developing mathematical resilience in parents: An illustrative case study. Creative Education, 6, 526-535. https://doi.org/10.4236/ce.2015.65052

Irawan, A., \& Kencanawaty, G. (2017). Implementasi pembelajaran matematika realistik berbasis etnomatematika [Implementation of ethnomathematics-based realistic mathematics learning]. Journal of Medives, 1(2), 74-81.

Johnston-Wilder, S., Lee, C., Garton, E., \& Brindley, J. (2014). Developing coaches for mathematical resilience: Level 2. In ICER2014 Proceedings, IATED Academy (pp. 4457-4465)

Komala, E. (2017). Mathematical resilience mahasiswa pada mata Kuliah Struktur Aljabar I menggunakan pendekatan explisit instruction integrasi peer instruction [Mathematical resilience of students in the Algebraic Structure I course uses an explicit approach of peer instruction integration]. Jurnal Mosharafa [Journal Musharraf], 6(3), 357-364. https://doi.org/10.31980/mosharafa.v6i3.324

Lugalia, M., Johnston-Wilder, S., \& Goodall, J. (2013). The role of ICT in developing mathematical resilience in learners. In Proceedings of the Seventh International Technology, Education and Development Conference (pp. 4096-4105).

Maharani, S., \& Bernard, M. (2018). Analisis hubungan resiliensi matematik terhadap kemampuan pemecahan masalah siswa pada materi lingkaran [Analysis of the relationship of mathematical resilience to students' problem-solving abilities on circle material]. Jurnal Pembelajaran Matematika Inovatif [Journal of Innovative Mathematics Learning], 1(5), 819-826. https://doi.org/10.22460/jpmi.v1i5.p819-826

Mawaddah, S., \& Maryanti, R. (2016). Kemampuan pemahaman konsep matematis siswa SMP dalam pembelajaran menggunakan model penemuan terbimbing [The ability to understand mathematical concepts of junior high school students in learning using the guided discovery model]. Jurnal Edu-Mat (Jurnal Pendidikan Matematika) [Edu-Mat Journal (Journal of Mathematics Education)], 4(1), 76-85. https://doi.org/10.20527/edumat.v4i1.2292

Nurhidayah, I. \&, \& Wangid, M. N. (2020). Pengembangan bahan ajar buku dongeng berbasis sainsmatika untuk meningkatkan pemahaman konsep [Development of science-based fairy tale book teaching materials to improve concept understanding]. Aksioma [Axiom], 9(2), 259-268. https://doi.org/10.24127/ajpm.v9i2.2688

Plomp, T., \& Nieveen, N. (2007). An introduction to educational design research. In Proceedings of the Seminar Conducted at the East China Normal University, Shanghai (PR China).

Putranti, S. D., \& Prahmana, R. C. I. (2018). Kemampuan siswa dalam menyelesaikan soal matematika berbasis masalah [Students' ability to solve problem-based math problems]. Jurnal JNPM [JNPM Journal], 2(1), 86-97. https://doi.org/10.33603/jnpm.v2i1. 943

Rafiana, A. K., \& Adirakasiwi, A. G. (2019). Studi korelasi antara self-esteem matematis dengan resiliensi matematis siswa [Correlation study between mathematical self-esteem and students' mathematical resilience]. In Prosiding Seminar Nasional Matematika Dan Pendidikan Matematika [Proceedings of the National Seminar on Mathematics and Mathematics Education] (pp. 796-802). http://journal.unsika.ac.id/index.php/sesiomadika

Sa'ud, U. S., \& Makmun, A. S. (2006). Perencanaan pendidikan suatu pendekatan komprehensif [Education planning a comprehensive approach]. PT Remaja Rosdakarya.

Safira, A. R., \& Ifadah, A. S. (2020). Pembelajaran sains dan matematika anak usia dini [Early childhood science and math learning]. Caremedia Communication.

Wangid, M. N., Mustadi, A., P, A. R., Hidayah, I. N., Herianingtyas, N. L. R., \& Mulyani, T. (2016). Urgensi pengembangan buku dongeng berbasis sainsmatika untuk menanamkan nilai-nilai karakter pada siswa sekolah dasar [The urgency of developing science-based fairy tale books to instill character values in elementary school students]. In Prosiding Seminar Nasional PGSD UST [Proceedings of the UST PGSD National Seminar] (pp. 206-216). 


\section{APPENDIX A - Mathematical Resilience Level Questionnaire Grid}

\begin{tabular}{|c|c|c|c|}
\hline No & $\begin{array}{l}\text { Aspects of mathematical } \\
\text { resilience }\end{array}$ & $\begin{array}{l}\text { Mathematical resilience } \\
\text { indicator }\end{array}$ & Statement \\
\hline \multirow{7}{*}{1} & \multirow{7}{*}{$\begin{array}{l}\text { Understanding of math } \\
\text { grades }\end{array}$} & \multirow{3}{*}{$\begin{array}{l}\text { Engage in mathematical } \\
\text { thinking }\end{array}$} & Thinking mathematically helps me with important things. \\
\hline & & & Math often gets me stuck in confusion. \\
\hline & & & I believe that mathematics can develop my thinking skills. \\
\hline & & \multirow{4}{*}{$\begin{array}{l}\text { Starting to experience } \\
\text { personal value in math }\end{array}$} & Mathematics has a high contribution to my learning goals so far. \\
\hline & & & Learning math does not bring any significant changes to my learning progress. \\
\hline & & & I have consciously implemented mathematics in my daily life. \\
\hline & & & I never knew the benefits and uses of learning math. \\
\hline \multirow{10}{*}{2} & \multirow{10}{*}{$\begin{array}{c}\text { (Mindset of growth) } \\
\text { Belief that brain abilities can } \\
\text { be developed }\end{array}$} & \multirow{4}{*}{ Strategy adaptation } & I like to work on different questions from questions that have been given previously. \\
\hline & & & I do not like doing math problems. \\
\hline & & & I re-learn about my wrong answers in doing math problems. \\
\hline & & & I'm not good at math, so I can't learn much math. \\
\hline & & \multirow{3}{*}{ Study skills } & I always believe I can come up with different ideas from other friends in the group. \\
\hline & & & I always fixate and leave everything to friends who are smarter in math. \\
\hline & & & I am confident when presenting my math answers in front of the class. \\
\hline & & \multirow{3}{*}{$\begin{array}{l}\text { Develop resilience in the face } \\
\text { of problems }\end{array}$} & I avoid solving math problems that have multiple solutions. \\
\hline & & & I am able to do math problems without giving up. \\
\hline & & & I like solving problems presented in math problems. \\
\hline \multirow{4}{*}{3} & \multirow{4}{*}{$\begin{array}{l}\text { Understanding of how to } \\
\text { work in math }\end{array}$} & \multirow{4}{*}{$\begin{array}{l}\text { Develop options \& } \\
\text { opportunities to experiment }\end{array}$} & I think wrongin doing mathit's important to better understand math. \\
\hline & & & I get confused easily when I'm wrong in doing math problems. \\
\hline & & & I can work on difficult math problems without giving up. \\
\hline & & & I always take failure in math exams as an experience to get better. \\
\hline \multirow{7}{*}{4} & \multirow{7}{*}{$\begin{array}{c}\text { Awareness of available } \\
\text { support from friends, } \\
\text { teachers, ICT, the Internet, } \\
\text { etc. }\end{array}$} & \multirow{4}{*}{ Access help \& support } & $\begin{array}{l}\text { I am embarrassed to seek help in solving problems that are different from the example } \\
\text { questions that have been given previously. }\end{array}$ \\
\hline & & & I am comfortable discussing concepts that have not been understood with friends. \\
\hline & & & I feel disturbed when asked for help by friends who have difficulty learning math. \\
\hline & & & I will ask the teacher if I do not understand a concept in math. \\
\hline & & \multirow{3}{*}{$\begin{array}{l}\text { Access media support \& } \\
\text { learning resources }\end{array}$} & I can easily access media and adequate mathematics learning resources. \\
\hline & & & I'm desperate when I can not find the source to complete the task. \\
\hline & & & In my opinion, learning mathematics only requires the provided textbook. \\
\hline
\end{tabular}




\section{APPENDIX B - Mathematical Resilience Level Questionnaire}

STUDENT MATHEMATIC RESILIENCE LEVEL QUESTIONNAIRE

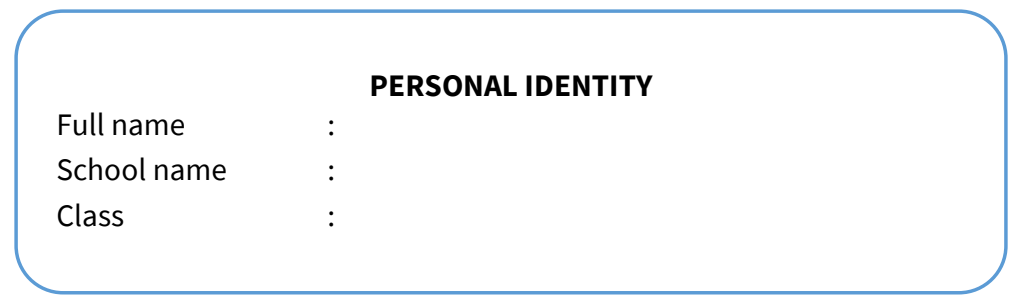

Fill in the following statements with a $(\checkmark)$ on one of the Yes/No answers. Answer the statements below honestly!

(This questionnaire does not affect the value of any subject)

\begin{tabular}{|c|c|c|}
\hline No & Statement & Yes \\
\hline 1 & Thinking mathematically helps me with important things. & \\
\hline 2 & Math often gets me stuck in confusion. & \\
\hline 3 & I believe that mathematics can develop my thinking skills. & \\
\hline 5 & Learning math does not bring any significant changes to my learning progress. & \\
\hline 6 & I have consciously implemented mathematics in my daily life. & \\
\hline 7 & I never knew the benefits and uses of learning math. & \\
\hline$\underline{9}$ & I do not like doing math problems. & \\
\hline 10 & I re-learn about my wrong answers in doing math problems. & \\
\hline 11 & I'm not good at math, so I can't learn much math. & \\
\hline 12 & I always believe I can come up with different ideas from other friends in the group. & \\
\hline 13 & I always fixate and leave everything to friends who are smarter in math. & \\
\hline 14 & I am confident when presenting my math answers in front of the class. & \\
\hline 15 & I avoid solving math problems that have multiple solutions. & \\
\hline 17 & I like solving problems presented in math problems. & \\
\hline 18 & I think wrongin doing mathit's important to better understand math. & \\
\hline 19 & I get confused easily when I'm wrong in doing math problems. & \\
\hline 20 & I can work on difficult math problems without giving up. & \\
\hline 21 & I always take failure in math exams as an experience to get better. & \\
\hline 22 & I am embarrassed to seek help in solving problems that are different from example questions that have been given previously. & \\
\hline 23 & I am comfortable discussing concepts that have not been understood with friends. & \\
\hline 24 & I feel disturbed when asked for help by friends who have difficulty learning math. & \\
\hline 25 & I will ask the teacher if I don't understand a concept in math. & \\
\hline 26 & I can easily access media and adequate mathematics learning resources. & \\
\hline 27 & I'm desperate when I can't find the source to complete the task. & \\
\hline 28 & In my opinion, learning mathematics only requires the provided textbook. & \\
\hline
\end{tabular}

Thank you for your honesty and participation. 
APPENDIX C - Questionnaire of Mathematical Resilience Levels Through Google Form

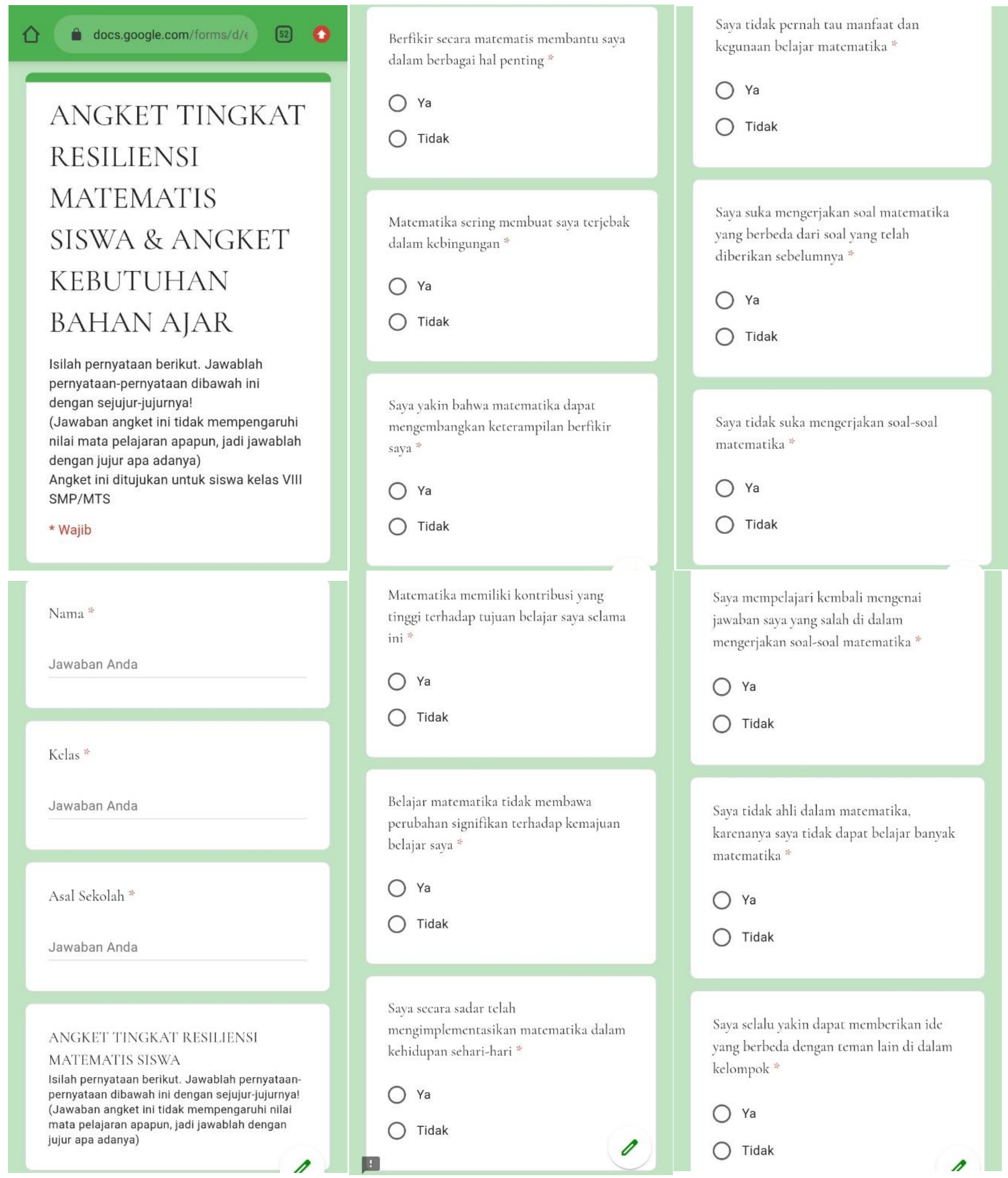




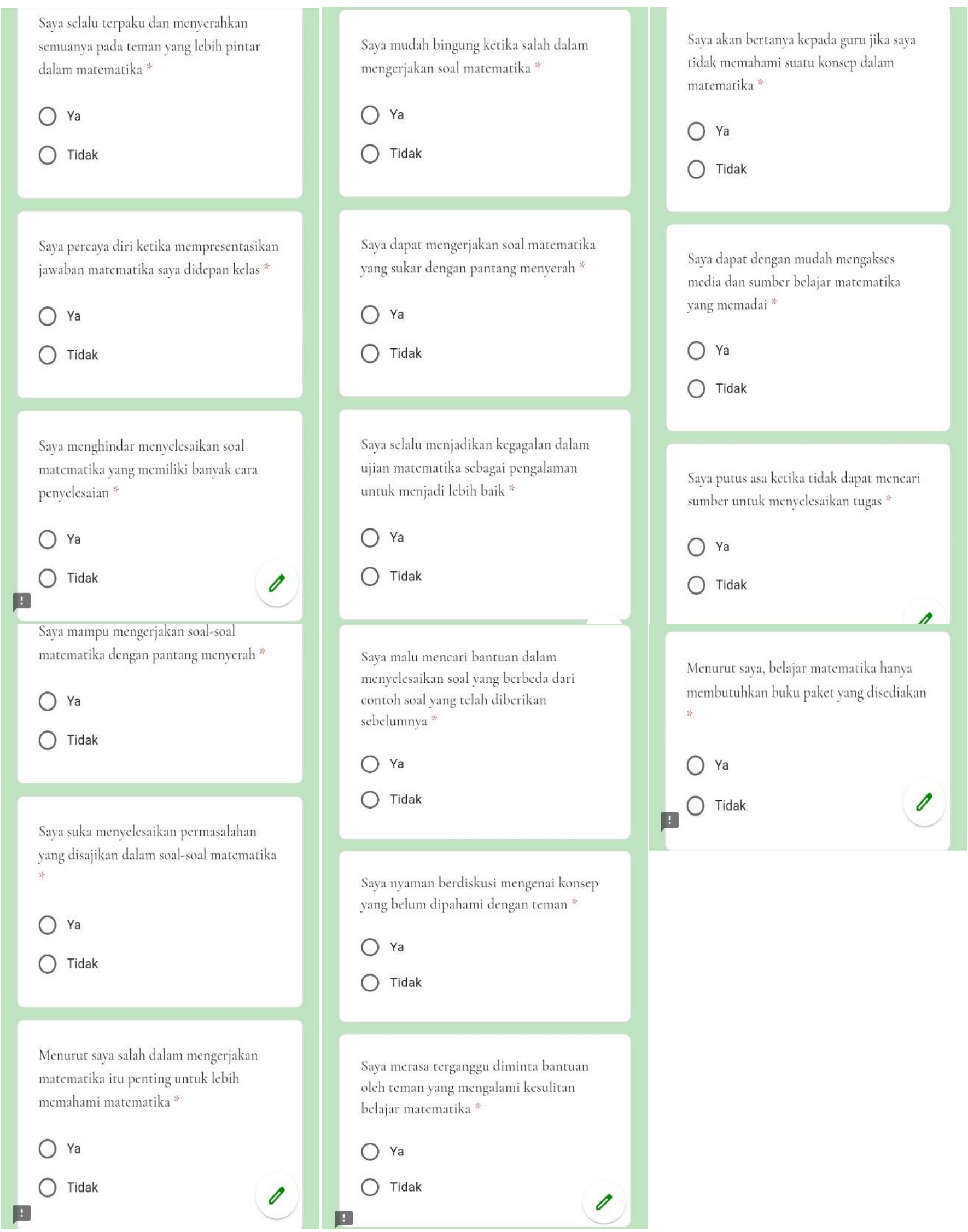




\section{APPENDIX D - Questionnaire Grid of Teaching Material Needs}

\section{No Aspects/characteristics Indicator \\ Statement}

The mathematics teaching materials that I use make me excited to learn independently.

The ability to teach

I find it difficult to learn mathematics from the Pythagorean material independently through students independently $\quad$ The mathematics teaching materials that I use make it easier for me to understand the the textbook I use. Pythagorean material independently.

Self-instructional

The mathematics teaching materials that I use make it easier for me to understand the

The mathematics teaching materials that I use provide space for me to be able to do the

Ability to train students practice questions independently. independently

I can't do the Pythagorean exercises in my math textbook. independently.

The mathematics teaching materials that I use contain Pythagorean material with complete and complete examples and practice questions.

$2 \quad$ Self-contained Full material loading for me to learn.

The mathematics teaching materials that I use contain a unified whole that makes it easier

The Pythagorean material contained in my math textbook is incomplete.

The teaching materials that I use are very complete so that I no longer need to look for other references in understanding the Pythagorean material.

$3 \quad$ Stand alone

Does not depend on other teaching materials

I need other references from the internet and other books to understand the material and Pythagorean math problems.

I need mathematics teaching materials for Pythagorean material that contain complete material, so that I can focus on studying only that one teaching material.

The Pythagorean material mathematics textbook that I use has not had a touch of current scientific and technological developments.

My math textbook has been integrated with the current innovations in the development of science and technology.
In accordance with the development of science \&
technology and technology.

If there is an innovative Pythagorean material textbook that adapts to the development of science, for example math material combined with science, I want to use it.

$4 \quad$ Adaptive

The Pythagorean mathematics textbook that I use is very old and irrelevant to current scientific developments.

Flexible to use within a $\quad$ My Pythagorean material math textbook is flexible to use for a long time. certain time

The Pythagorean mathematics textbook that I use has not adapted to the current development of science.

I am sure that the innovative Pythagorean textbook that combines mathematics and science with an interesting storyline will really help me in learning mathematics. The language used in math textbooks is difficult for me to understand.

I can easily understand the Pythagorean material with the language used in the textbook I

Use simple language use.

I can't understand the Pythagorean material with the language in my textbook.

I need a Pythagorean textbook that contains science and mathematics with a simple language presentation that makes it easier for me to understand the material.

$5 \quad$ User friendly

The math terms in my Pythagorean math textbook are easy to understand.

Use of commonly used terms 


\section{APPENDIX E - Questionnaire on the Level of Teaching Material Needs}

\section{PYTHAGORAS MATHEMATICS TEACHING MATERIAL REQUIREMENTS QUESTIONNAIRE BASED ON SCIENCE FOR}

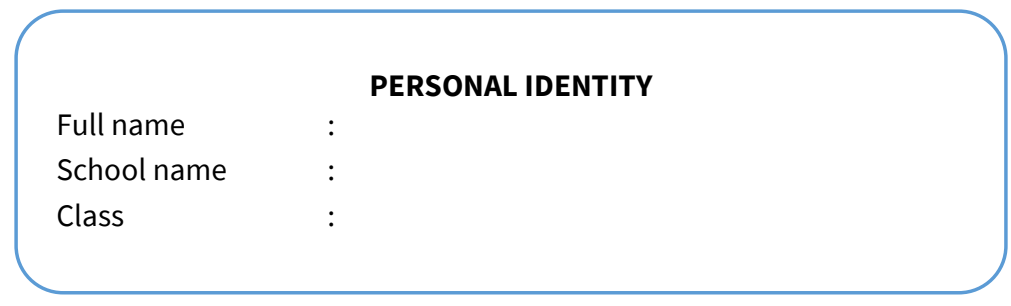

Fill in the following statements with a $(\checkmark)$ on one of the Yes/No answers. Answer the statements below honestly!

(This questionnaire does not affect the value of any subject)

\begin{tabular}{|c|c|c|c|}
\hline No & Statement & Yes & No \\
\hline 1 & The mathematics teaching materials that I use make me excited to learn independently. & & \\
\hline 2 & I find it difficult to learn Pythagorean mathematics independently through the textbook I use. & & \\
\hline 3 & The mathematics teaching materials that I use make it easier for me to understand the Pythagorean material independently. & & \\
\hline 4 & The mathematics teaching materials that I use provide space for me to be able to do the practice questions independently. & & \\
\hline 5 & I can't do the Pythagorean exercises in my math textbook. & & \\
\hline 6 & I find it difficult to understand the practice of Pythagorean math problems in the textbook independently. & & \\
\hline 7 & $\begin{array}{l}\text { The mathematics teaching materials that I use contain Pythagorean material with complete and complete examples and practice } \\
\text { questions. }\end{array}$ & & \\
\hline 8 & The mathematics teaching materials that I use contain a unified whole that makes it easier for me to learn. & & \\
\hline 9 & The Pythagorean material contained in my math textbook is incomplete. & & \\
\hline 10 & $\begin{array}{l}\text { The teaching materials that I use are so complete that I no longer need to look for other references in understanding Pythagorean } \\
\text { material. }\end{array}$ & & \\
\hline 11 & I need other references from the internet and other books to understand the material and Pythagorean math problems. & & \\
\hline 12 & $\begin{array}{l}\text { I need Pythagorean mathematics teaching materials that contain complete material, so that I can focus on studying only that one } \\
\text { teaching material. }\end{array}$ & & \\
\hline 14 & My math textbook has been integrated with the current innovations in the development of science and technology. & & \\
\hline 15 & I have never used an innovative textbook that adapts to the current development of science and technology. & & \\
\hline 16 & $\begin{array}{l}\text { If there is an innovative Pythagorean material textbook that adapts to the development of science, for example mathematics } \\
\text { combined with science, I want to use it. }\end{array}$ & & \\
\hline 17 & The Pythagorean math textbook that I use is very old and irrelevant to the current development of science. & & \\
\hline 18 & My Pythagorean math textbook is flexible to use for a long time. & & \\
\hline 19 & The Pythagorean mathematics textbook that I use has not adapted to the current development of science. & & \\
\hline 20 & $\begin{array}{l}\text { I'm sure the innovative Pythagorean textbook that combines math and science with an interesting storyline will really help me in } \\
\text { learning math. }\end{array}$ & & \\
\hline 21 & The language used in math textbooks is difficult for me to understand. & & \\
\hline 22 & I can easily understand the Pythagorean material with the language used in the textbook I use. & & \\
\hline 23 & I can not understand the Pythagorean material with the language in my textbook. & & \\
\hline 24 & $\begin{array}{l}\text { I need a Pythagorean textbook that contains science and mathematics with a simple language presentation that makes it easier for } \\
\text { me to understand the material. }\end{array}$ & & \\
\hline 27 & th the use of easy-to-understand mathematical terms to help understand the Pythagorean material. & & \\
\hline
\end{tabular}

Thank you for your honesty and participation. 
APPENDIX F - Questionnaire on the Level of Teaching Material Needs Through Google Form

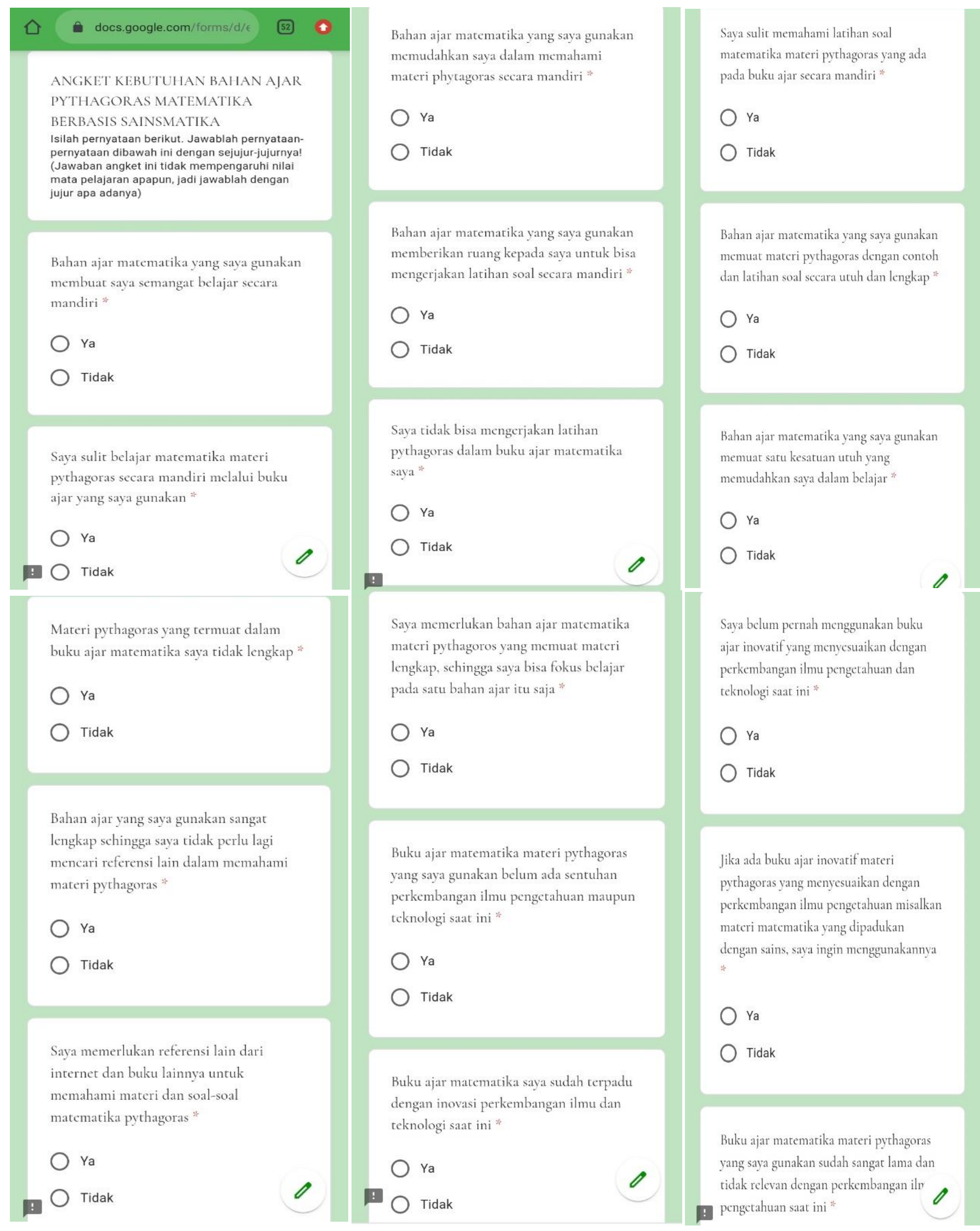


Buku ajar matematika materi pythagoras yang saya gunakan sudah sangat lama dan tidak relevan dengan perkembangan ilmu pengetahuan saat ini *
Ya
Tidak

Buku ajar matematika materi pythagoras saya pleksibel untuk digunakan dalam kurun waktu yang panjang *

\section{$\bigcirc \mathrm{Ya}$ \\ Tidak}

Buku ajar matematika materi pythagoras yang saya gunakan belum menyesuaikan dengan perkembangan ilmu saat ini *

\section{Ya \\ $\bigcirc$ Tidak \\ :}

Istilah yang digunakan dalam buku ajar matcmatika saya matcri pythagoras sangatlah rumit *
○ Ya
Tidak

Saya memerlukan bahan ajar dengan penggunaan istilah matematika yang mudah dipahami untuk membantu memahami materi pythagoras *

\section{$\mathrm{O}$ Ya \\ Tidak}

\section{Kirim}

Jangan pernah mengirimkan sandi melalui Google Formulir.

Konten ini tidak dibuat atau didukung oleh Google. Laporkan Penyalahgunaan - Persyaratan Layanan Kebijakan Privasi
Saya yakin buku ajar inovatif materi pythagoras yang memadukan matematika dan sains dengan alur cerita yang menarik akan sangat membantu saya dalam belajar matemarika *

\section{$\bigcirc \mathrm{Ya}$}

\section{Tidak}

Bahasa yang digunakan dalam buku ajar matematika sulit saya pahami *
$\bigcirc \mathrm{Ya}$
Tidak

Saya mudah memahami materi pythagoras dengan bahasa yang digunakan dalam buku ajar yang saya gunakan *

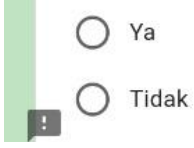

Saya tidak bisa memahami materi pythagoras dengan bahasa yang ada pada buku ajar saya "

$\bigcirc$ Ya

Tidak

Saya memerlukan buku ajar pythagoras yang memuat sains dan matematika dengan penyajian bahasa yang sederhana schingga memudahkan saya dalam memahami materi *

$\bigcirc \mathrm{Ya}$

Tidak

Istilah matematika yang ada dalam buku ajar matematika materi pythagoras saya mudah di pahami *

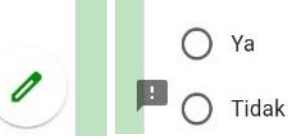




\section{APPENDIX G - Mathematical Resilience Level Questionnaire Validation Sheet}

\section{VALIDATION SHEET \\ MATHEMATIC RESILIENCE LEVEL QUESTIONNAIRE}

Validator name:

NIP/NIDN:

Areas of expertise:

\section{A. Introduction}

This validation sheet is used to obtain your assessment of students' mathematical resilience questionnaires. I thank you for your willingness to be a validator and fill out this validation sheet.

\section{B. Instruction}

1. You are requested to give a score for each item of the statement by ticking $(\checkmark)$ in the column with the rating scale, as follows: V=Valid; TV=Invalid

2. If necessary, you can provide criticism and suggestions for improvement in the lines provided.

\section{Evaluation}

\begin{tabular}{|c|c|c|c|}
\hline \multirow{2}{*}{ Indicator } & \multirow{2}{*}{ Statement } & Evaluation & \\
\hline & & TV & \\
\hline \multirow{3}{*}{$\begin{array}{l}\text { Engage in } \\
\text { mathematical } \\
\text { thinking }\end{array}$} & Thinking mathematically helps me with important things. & & \\
\hline & Math often gets me stuck in confusion. & & \\
\hline & I believe that mathematics can develop my thinking skills. & & \\
\hline \multirow{4}{*}{$\begin{array}{l}\text { Starting to } \\
\text { experience personal } \\
\text { value in math }\end{array}$} & Mathematics has a high contribution to my learning goals so far. & & \\
\hline & Learning math does not bring any significant changes to my learning progress. & & \\
\hline & I have consciously implemented mathematics in my daily life. & & \\
\hline & I never knew the benefits and uses of learning math. & & \\
\hline \multirow{4}{*}{ Strategy adaptation } & I like to work on different questions from the questions that have been given previously. & & \\
\hline & I do not like doing math problems. & & \\
\hline & I re-learn about my wrong answers in doing math problems. & & \\
\hline & I'm not good at math, so I can't learn much math. & & \\
\hline \multirow{3}{*}{ Study skills } & I always believe I can come up with different ideas from other friends in the group. & & \\
\hline & I always fixate and leave everything to friends who are smarter in math. & & \\
\hline & I am confident when presenting my math answers in front of the class. & & \\
\hline \multirow{2}{*}{$\begin{array}{l}\text { Develop resilience in } \\
\text { the face of problems }\end{array}$} & I am able to do math problems without giving up. & & \\
\hline & I like solving problems presented in math problems. & & \\
\hline \multirow{4}{*}{$\begin{array}{l}\text { Develop options \& } \\
\text { opportunities to } \\
\text { experiment }\end{array}$} & I think wrongin doing math is important to better understand math. & & \\
\hline & I get confused easily when I'm wrong in doing math problems. & & \\
\hline & I can work on difficult math problems without giving up. & & \\
\hline & I always take failure in math exams as an experience to get better. & & \\
\hline \multirow{4}{*}{$\begin{array}{l}\text { Access help \& } \\
\text { support }\end{array}$} & $\begin{array}{l}\text { I am embarrassed to seek help in solving problems that are different from the example questions that } \\
\text { have been given previously. }\end{array}$ & & \\
\hline & I am comfortable discussing concepts that have not been understood with friends. & & \\
\hline & I feel disturbed when asked for help by friends who have difficulty learning math. & & \\
\hline & I will ask the teacher if I don't understand a concept in math. & & \\
\hline \multirow{3}{*}{$\begin{array}{l}\text { Access media } \\
\text { support \& learning } \\
\text { resources }\end{array}$} & I can easily access media and adequate mathematics learning resources. & & \\
\hline & I'm desperate when I can't find the source to complete the task. & & \\
\hline & In my opinion, learning mathematics only requires the provided textbook. & & \\
\hline
\end{tabular}

\section{Comments and Suggestions}

\section{E. Conclusion}

Based on the assessment that has been carried out, the student's mathematical resilience level questionnaire sheet is stated:

a. Worth using without revision

b. Worth using with revision

c. Not worth using

Please put a circle mark on the number that corresponds to your conclusion. 


\section{APPENDIX H - Pythagorean Module Validation Sheet Based on Science}

\section{VALIDATION SHEET \\ PYTHAGORAS MODULE BASED ON SCIENCE}

Validator name:

NIP/NIDN:

Areas of expertise:

\section{A. Introduction}

This validation sheet is used to obtain your assessment of the science-based Pythagorean module in constructing students' mathematical resilience. I thank you for your willingness to be a validator and fill out this validation sheet.

\section{B. Instruction}

1. You are requested to give a score for each item of the statement by ticking $(\checkmark)$ in the column with the rating scale, as follows: 4=Very eligible; $3=$ =Eligible; $2=$ =Less eligible; $1=$ Not eligible

2. If necessary, you can provide criticism and suggestions for improvement in the lines provided.

\section{Evaluation}

\begin{tabular}{|c|c|c|c|c|c|}
\hline \multirow{2}{*}{ Rating indicator } & \multirow{2}{*}{ Rating points } & \multicolumn{4}{|c|}{ Evaluation } \\
\hline & & 1 & 2 & 3 & 4 \\
\hline \multicolumn{6}{|l|}{ Content feasibility aspect } \\
\hline \multirow{3}{*}{$\begin{array}{l}\text { A. Suitability of material with } \\
\text { KD }\end{array}$} & 1. Material equipment & & & & \\
\hline & 2. Material breadth & & & & \\
\hline & 3. Material depth & & & & \\
\hline \multirow{3}{*}{ B. Material accuracy } & 4. Concept and definition accuracy & & & & \\
\hline & 5. Example and case accuracy & & & & \\
\hline & 7. Accuracy of terms & & & & \\
\hline \multirow{2}{*}{ C. Material update } & 8. Suitability of the material, examples, \& questions that are relevant to current scientific developments & & & & \\
\hline & 9. Using examples and cases found in everyday life & & & & \\
\hline \multirow{2}{*}{ D. Encourage curiosity } & 10. Encourage curiosity & & & & \\
\hline & 11. Creating the ability to ask questions & & & & \\
\hline \multicolumn{6}{|c|}{ Aspects of feasibility of presentation } \\
\hline \multirow{2}{*}{ A. Presentation technique } & 1. Concept collapse & & & & \\
\hline & 3. Practice questions at the end of each sub material & & & & \\
\hline \multirow[t]{3}{*}{ B. Presentation support } & 4. Introduction & & & & \\
\hline & 5. Bibliography & & & & \\
\hline & 6. Explanation and description of the contents of the module & & & & \\
\hline \multirow{2}{*}{$\begin{array}{l}\text { C. Coherence \& coherence of } \\
\text { flow of teaching materials }\end{array}$} & 7. Regularity between activities in teaching materials & & & & \\
\hline & 8. Integrity of meaning in teaching materials & & & & \\
\hline \multicolumn{6}{|l|}{ Language eligibility aspect } \\
\hline \multirow{3}{*}{ A. straightforward } & 1. The accuracy of sentence structure & & & & \\
\hline & 2. Sentence effectiveness & & & & \\
\hline & 3. Term standard & & & & \\
\hline B. Communicative & 4. Understanding of messages or information & & & & \\
\hline C. Dialogic \& interactive & 5. Ability to motivate students & & & & \\
\hline \multirow{2}{*}{$\begin{array}{l}\text { D. Suitability with the } \\
\text { development of students }\end{array}$} & 6. Conformity with the intellectual development of students & & & & \\
\hline & 7. Conformity with the level of emotional development of students & & & & \\
\hline $\begin{array}{l}\text { E. Conformity with language } \\
\text { rules }\end{array}$ & 8. Grammatical accuracy & & & & \\
\hline \multirow[b]{2}{*}{ A. The nature of science } & 1. The relationship between the material presented and scientific situations in everyday life & & & & \\
\hline & $\begin{array}{l}\text { 2. The ability to encourage students to make connections between their knowledge of science and } \\
\text { mathematics and their application in everyday life }\end{array}$ & & & & \\
\hline \multirow{2}{*}{ B. Scientific component } & 3. Relation of science and mathematics to Pythagorean material & & & & \\
\hline & 4. The attachment of scientific elements in the presentation of material and questions & & & & \\
\hline
\end{tabular}

\section{Comments and Suggestions}




\section{E. Conclusion}

Based on the assessment that has been carried out, the student's mathematical resilience level questionnaire sheet is stated:

a. Worth using without revision

b. Worth using with revision

c. Not worth using

Please put a circle mark on the number that corresponds to your conclusion.

Cirebon, .......................2021

validators,

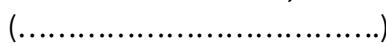

